\title{
報交
}

\section{ポリエステル綫維の微細組織中における ジエチレングリコール成分の分布}

株式会社クラレ中央研究所 赤羽健志・中保治郎・梶谷浩一

\section{DISTRIBUTION OF DIETHYLENE GLYCOL COMPONENT IN THE FINE TEXTURE OF POLYESTER FIBERS}

\author{
By Takeshi Akahane, Haruo Nakayasu and Koichi Kajitani \\ (Central Research Laboratories, Kuraray Co. Ltd., \\ 2045-1, Aoeyama, Sakazu, Kurashiki, 710 Japan)
}

\begin{abstract}
Distribution of diethylene glycol (DEG) component in the fine texture of polyester fibers has been investigated by measuring the concentrations of DEG in the decomposed and the residual portions obtained by heterogeneous aminolysis of the fibers using monomethylamine. The result shows that the region having higher DEG content decomposes more easily in both fibers of polyethylene terephthalate (PET) and copolyester having DEG as one glycol component.

The tendency becomes remarkable as the temperature of the heat treatment of the fibers prior to the aminolysis is increased. From the analyses of the data obtained by gel permeation chromatography of the residual portion and of the crystallinity by X-ray and infrared spectroscopy, it is shown that aminolysis proceeds successively from the amorphous region where amine can easily pass into. Even in the heat treatment of PET fibers, crystallization occurs by squeezing the DEG rich portion out to the amorphous region, resulting in the increase of DEG concentration in the amorphous region. The change in the dyeing behavior of fibers by heat treatment can be reasonably explained by taking account of the quality change of the amorphous region due to the increase of DEG.
\end{abstract}

(Received October 11, 1979)

\section{1. 緒言}

ポリエチレンテレフタレート(PET)を製造する場合，

副反応によるジエチレングリコール(DEG)成分を絶無 にすることは困難であり，市販のPET織維には通常 2 モルタ前後のDEG成分が存在する”。とのようなPET 維維を熱処理すると，非晶領域にDEG成分に富む部分 が渄縮されるといった一種の分別結晶化が起てれは，非 晶領域にDEGがより多く分布し，その程度は熱処理条 件で異なることが期待される。また，微細組織におりる このようなDEG漕度の分布が生じるならば，それは織
維の物性，特に染色性などに影響を与えるすのと予想さ れる。

そてで通常のPET䋐維だけでなく，グリコール成分 の一つとしてDEGを皘極的に共縮合させて得たポリエ ステル(PES) 紷維について，熱処理温度を変え，モ， メチルアミン水溶液で処理して分解液および分解残渣中 のDEGを定量するととにより，まずDEG成分の分布の 測定を試みた。その結果，アミン分解の初期に重量减少 する，アミンが浸透し易い領域にDEGがより多く存在 するととを認めたので報告する。また，とのような DEG の分布が絩維の染着性に与える影響についても諭じる。 
PET緎維のアミン処理については，非晶領域を取り 除き結晶領域を分離する目的で，熱履歴の異なる瀻維を モノメチルアミン水溶液で処理した結果がFarrow ら ${ }^{2)}$ に上って最初に報告された。被らはアミン分解の初期に は，アミンの浸透し易い非晶領域加ら分解汃進むと考え た。しかし，アミン分解がかなり進んでもX線的に求め た結晶化度が72\%以上に增大しないことなどから，非晶 領域と結晶領域との分離は明確にはできなかったとして いる。その後栗田 ${ }^{3)}$ は非晶領域之結晶領域との分離をさ らによくする目的で, モノエチルアミンの70\%水溶液で PET䄉維を姏理して研究した。この方法はその後関根 $ら^{4,5)}$ にってPETフィルムの構造研究に適用された。

本研究で用いたモノメチルアミン水容液によるアミン 分解の性格についても，分解残渣のgel permeation chromatography，X線法および赤外法による結晶性な どで検討した。

\section{2. 奏駗}

\section{1 試 料}

酸化チタンを添加せずに，通常の溶融紡系法で得た緎

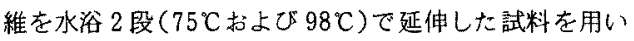
た。〔ク]の測定はフェノールーテトラクロロエタン (50/ $50, \mathrm{w} / \mathrm{w})$ の系で $30^{\circ} \mathrm{C} て ゙$ 行な，単位ば $\mathrm{dl} / \mathrm{g}$ である

1) PET满維：4倍延伸した, [ク]=0.57で, DEGを 1.9 モル名含有するものである。その強度は $3.5 \mathrm{~g} / \mathrm{d}$, 伸 度は $45 \%$ であった。

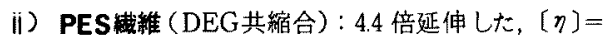
0.50 で, DEGを 11 モル\%含有し，その強度は $3.7 \mathrm{~g} / \mathrm{d}$ ， 伸度は $41 \%$ あ゙あった。

これらの䋞維の熱処理は，真空乾燥試料老定長下にシ リコンオイル中で 30 分間行ない，nーへキサンでソック スレー抽出して付着オイルを除去した。

\section{2 アミン処理条件の選定}

モノメチルアミンの濃度および処理温度を変え，緘維 の 50\%重量減少に要する時間を目安に，浴比 $50: 1$ で 検討した。分解残洫はガラスフィルターNo.4で沪し取 り水洗した後，約 $100^{\circ} \mathrm{C}$ のチレングリコールで抽出姏 理し,さらに水洗，乾燥して秤冒した。

分解速度はアミン濃度に著しく依存し，濃度が 2 倍に なれば分解速度は約 3 倍に達した。室温付近で処理温度 が $10^{\circ} \mathrm{C}$ 上昇すると分解速度は約 2 倍になった。これらの 結果から， $150 \mathrm{~g} / l$ 濃度で 30 C で処理するのがよいと 判断した。

\section{3 分解液およひ分解残渣中のDEGの定量}

アミン分解液中の DEGは上澄液を直接水萃イオン化 ガスクロマトグラフにより，エチレングリコールのピー
クと対比して測定した。分解残渣についてはさらにヒド ラジン水溶液で分解してから，同様にガスクロマトグラ フで測定した ${ }^{\theta)}$ 。

\subsection{GPC(Gel Permeation Chromatography)}

Waters社製のGPC装置を用い，DMF（ジメチルホル ムアミド)を溶媒しして，130 Cで測定した。

\section{5 赤外およびX線測定}

赤外吸収スペクトルは $\mathrm{KBr}$ 錠剂法で測定し，赤外法に よる結晶性の尺度 ${ }^{7)}$ とされている $D_{972} / D_{795}\left(D_{972}\right.$ ，およ び $D_{798}$ はそれぞれ 972 および795力イザーの吸収ピーク の光学密度)を算出した。

$\mathrm{X}$ 線湖定は理学電機製 X 線回折装置を用い，常法によ り行なった。X線法による結晶化度， $\alpha_{\mathrm{C}}$ ，は2 $\theta=8$ 〜 $40^{\circ}$ で，回転試料台を用いて䋐維状試料の配向の影響を 平均化し，Farrow ら ${ }^{8}$ の方法に従って算出した。

\section{3. 実験結果ならひに考察}

\section{1 アミン分解の進行にともなうDEG浱度の} 要化

熱処理温度を変えた一連の䋐維試料について, 150 g/ lのモノメチルアミン水溶液を用い，30 Cで時間を变え て処理し，溶液中お上び分解残渣中の総アルコール成分 に対するDEG成分のモル濃度を測定した。その結果， $\mathrm{PET}$ 枋よびPES緎維の場合ともに，アミン分解の進行 とともに残渣中の DEG成分は減少し，その傾向は熱炕 理盜度が高いはど䡩著であるととを認めた。なお，分解 液中の DEG濃度は，分解残渣中の濃度より逆算される 檤とよく一致した。

一連のアミン処理時間を変えた実験についての測定結 果を用いて，順次，次の処理時間までの間记重量隇少し た部分の DEG 濃度の平均值を算出した。熱処理温度の 巽なる二，三のPET䋐維についての結果を図1に，ま たPES緎維の場合を図2に示す。いずれの場合も，ア ミン分解の初期に脱洛する部分住どDEG濃度が高いこ とがわかる。その傾向は熱処理温度が高いはど明暸であ

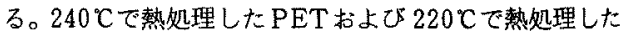
PES 䄉維の場合には，ともに最初の重量減少部分には 平均値の二倍以上のDEGが存在し，最後の分解残渣中 のDEG濃度は平均值の約半分になっていることがわか る。

これらの結果から，DEGの分布の様子はDEGの平均 の值にはあまり関係なく，主として熱好理の温度によっ て変わることがわかる。

3.2 モノメチルアミンによる释の分解举功

本奏験条件でのモ/メチルアミンによる分解の性格に ついて，3.1で得た結果の解釈之も関連するので，主と 


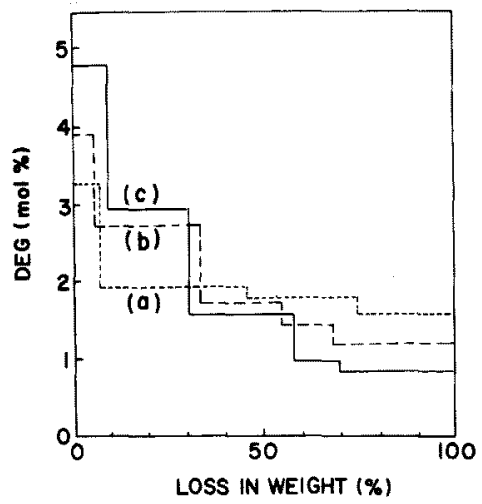

Fig. 1. DEG concentration (mol\%) in successive fraction of loss in weight of PET fibers during aminolysis, (a) unheated fiber, (b) fiber heated at $200^{\circ} \mathrm{C}$, (c) fiber heated at $240^{\circ} \mathrm{C}$.

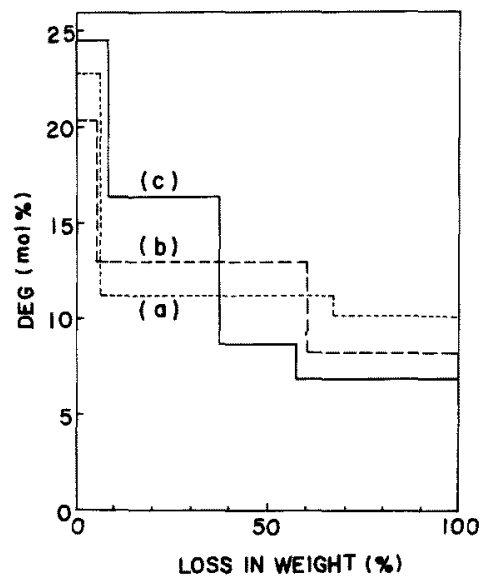

Fig. 2. DEG concentration ( $\mathrm{mol} \%$ ) in successive fraction of loss in weight of PES fibers during aminolysis, (a) unheated fiber, (b) fiber heated at $150^{\circ} \mathrm{C}$, (c) fiber heated at $220^{\circ} \mathrm{C}$.

してPES綪維の場合を例示して以下に論ずる。

3.2 .1 分解残楂のGPC

PETおよびPESのアミン処理時間を変えた一連の試 料についてGPCを测定した。200Cで熱処理した，(ク) $=0.48$ の PES 緟維と，それを 24 時間アミン処理して $45.1 \%$ 重量減少した分解残渣 $([\eta]=0.11)$ 亿つての結 果を図 3 に示す。

図 3からわかるように，分解残䄑のGPC曲線は未分 解物のをれに比べてピークの形状が鋭く，ビークの位置

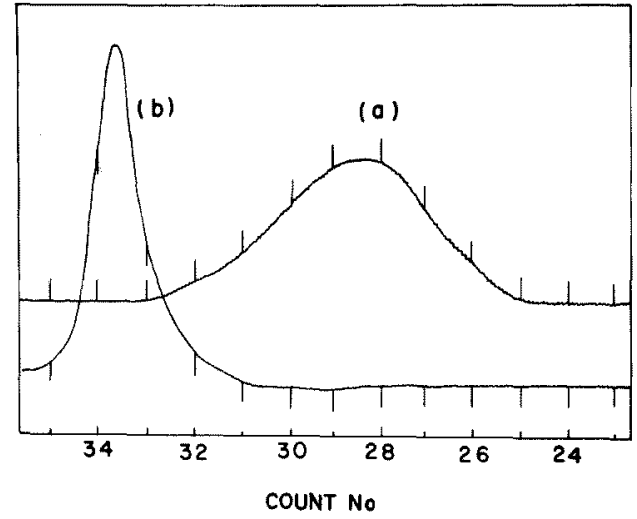

Fig. 3. A result of gel permeation chromatography measurements on two samples; (a) PES fiber heated at $200{ }^{\circ} \mathrm{C}$, (b) the fiber degraded for 24 hours.

は著しく低分子量(高カウント数)側一移動している。こ のピークの位置は分子銷長で約 $90 \AA$ (重合度では約 9) に相当する ${ }^{0)}$ 。との值は，分解前の試料についての結晶 の長さの尺度とされる(105)のX線回折の広がりから算 出された $D_{(\overline{1} 0 \mathrm{~b})}=74 \AA$ 之，結晶領域と韭晶領域の長さの 和の尺度とされる，X線小角散乱より求められた LP (長周期) $=114 \AA$ 它の中間の値走示している。この結果 は，乙の試料の場合には非晶領域の分解がはぼ終了し， 分解残渣中の分子鎖長は結晶の分子鎖方向の長さにはほ 対応した，分有の鋭いものになったてとを示すと考えら れる。乙れは，メチルアミンによる分解も，分解の初期 には，エチルアミンによる場合と同様にアミンの浸透し 易い非晶領域から順次進行することを示すすのと推察さ れる。

なお，図は省略するが，200Cで熱処理したPET㵶維 $((\eta)=0.56)$ を 48 時間アミン処理して, 重量减少が 47.8 \%みられた分解残渣 $([\eta]=0.14)$ につては，ピークの 位置が重合度約 10 に相当するGPC曲線を得た。PET

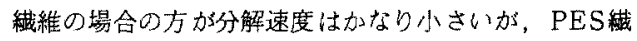
維の場合之同様にアミン分解が進行すると考えられる。

\section{2 .2 分解残澘の結晶性}

アミン分解の性格をさらに明らかにするために，分解 にとあなう結晶性の変化をX線法と赤外法とで調べて対 比した。結果の一部を表 1 に示す。いずれの試料につい ても重屋減少が大きいはど $\alpha_{\mathrm{C}}$ および $D_{972} / D_{705}$ の值はと むに增大していることがわかる。

$ア$ アン処理前の熱処理温度を変えた $\mathrm{PES}$ 㵶維の $\alpha_{\mathrm{C}}$ と $D_{972} / D_{795}$ との関係を図 4 kO印で示す。対応する笘囲 はややせまいが，図に示したように再者の関係はややわ 
Table 1. Change in degree of crystallinity $\left(\alpha_{c}\right)$ measured by $\mathrm{X}$-ray method and $D_{972} / D_{795}$ of infrared absorption during aminolysis of the PES fibers heated at different temperatures for 30 minutes.

\begin{tabular}{c|c|c|c|c}
\hline $\begin{array}{c}\text { Heat treatment } \\
\text { temperature (C) }\end{array}$ & $\begin{array}{c}\text { Time of } \\
\text { aminolysis } \\
\text { (hrs.) }\end{array}$ & $\begin{array}{c}\text { Loss in weight } \\
(\%)\end{array}$ & $\begin{array}{c}\text { Degree of } \\
\text { crystallinity } \\
(\%)\end{array}$ & $D_{872} / D_{785}$ \\
\hline \multirow{3}{*}{ unheated } & 0 & - & 23.9 & 0.41 \\
& 24 & 6.2 & 35.3 & 0.62 \\
& 31 & 67.5 & 46.8 & 1.0 \\
150 & 36 & 80.6 & 50.1 & 1.1 \\
\hline \multirow{5}{*}{180} & 24 & - & 40.5 & 0.53 \\
& 36 & 5.5 & 47.3 & 0.71 \\
& 48 & 80.3 & 50.8 & 1.3 \\
& 0 & - & 62.0 & 1.4 \\
\hline \multirow{5}{*}{220} & 16 & 3.3 & 42.5 & 0.65 \\
& 34 & 18.6 & 49.3 & 0.75 \\
& 0 & 85.0 & 53.5 & 1.0 \\
& 8 & - & 65.1 & 2.5 \\
\hline & 16 & 7.9 & 48.1 & 0.72 \\
& 24 & 37.8 & 50.1 & 0.95 \\
& 36 & 57.4 & 58.4 & 1.6 \\
& 0 & 78.0 & 63.5 & 2.3 \\
& & & 70.0 & 2.6 \\
\hline
\end{tabular}

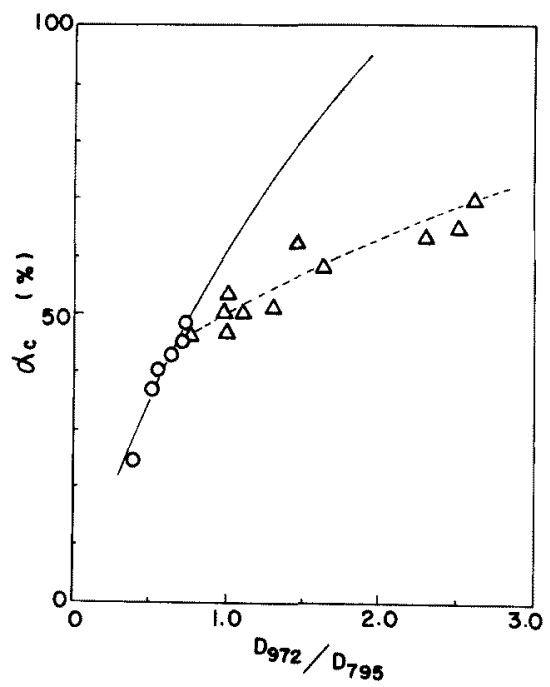

Fig. 4. Relationship between the crystallinity $\left(\alpha_{c}\right)$ measured by X-ray method and $D_{972} / D_{795}$ of PES fibers (O) heated at different temperatures and of degraded residues of the fibers $(\Delta)$.

ん曲した実線で近似できそうである。一方，分解残楂に

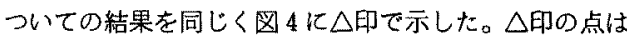
ややばらついているか，ての場合はほぼ点線のように近 似でき，点線の勾配は実線の場合よりもかなり小さいて
とがわかる。分解が進むとX 線法之赤外法との值化系統的 な差が生じたすのと推察され る。

四 4 で実線と点線の差が生 じた原因の一つは、アミン分 解かある程度進行した場合に は，分解残渣の結晶化度を椡 定したX線回折のチャートを みると，回折ピークの半価幅 は明らかに增大しているので, 分解残渣中の結晶粒径は小さ くなり。また結晶領域で部 分的任分解をうりて格子久陷 等が增大していると考えられ， そのためにX線法比よる $\alpha_{\mathrm{c}}$ の測定の際， $2 \theta=19.5^{\circ}$ では 結晶による回折の寄与かない とする Farrow ら" の仮定加 次第に成立しなくなり，分解 が進むはど $\alpha_{\mathrm{c}}$ 実際よりも 小さめに算出されたためと思われる。Farrowら ${ }^{2)} の も$ ノメチルアミンによるPET織維の処理の場合に, 分解 残梢の $\alpha_{\mathrm{c}}$ 加 72\% (本実験のPES峨維の場合には 70\%) 以上にならなかったのは，一つには上述したように的 の算出の仮定に問題が生じたためであろう。

一方，モノエチルアミンを用いた栗田 ${ }^{8}$ の研究伒い て屯，Farrow $ら^{8)}$ の場合之同様の仮定でX線的に求め た $\alpha_{\mathrm{c}}$ は，了ミン処理前に31およひ34\%の6のが, 了ミ ン処理か進んであをれぞれ 54 および51\%を越えなかっ たと報告されている。との場合も分解残渣の $\alpha_{\mathrm{c}}$ は，上 述した理由により実際よりも低目に算出されていると推 察されるが，このDataに関する限りモノエチルアミン による分解の方が，モノメチルアミンを用いる場合より 屯非晶領域と結晶領域との分離が良好であったとは考え 難いように思好れる。

そのようになった原因の一つは，モノエチルナミンは steric factorのために同一濃度で比較すれば反応速度 はモノメチルアミンの場合に比へて確加約 $1 / 8$ と小さ いが，70\%という高曟度を用いているために，初期の重 量隇少速度は $150 \mathrm{~g} / 1$ のノメチルアミンを用いた場合 よりもむしろ大きくなったためであろう。70\%のモノエ チルアミンを用いてPETフィルムを処理した関根ら゙の 報告では，処理フィルムの表面に結晶一非晶といったオ ーダーよりもはるが似大きい，数十 $\mu \mathrm{m}$ の䈉状のエッ チング・パターンが形成され，表面層はブロック的に脱 
落する場合があるととす钼察されている。

いすれにしてもアミン分解反応ではポリエステルの結 晶相之非結晶相とを理想的に分離するととは困難と思わ れるが，率直に考えて，アミンが漫透し易い領域，すな わち非晶領城や結晶領域であ微細な部分あるいは欠楩部 分にDEG成分が多く存在し易いという本実験の結諭に は変わりがないであろう。

\section{2 .3 重量減少速度と分解残渣の $[\eta]$}

熱好理温度を変えた䋐維試料について，時間を変えて アミン処理し，処理時間と重量减少率との関係図を得て, それを図上微分して重量减少速度上処理時間との関係を 求めた。PES繊維の場合を図 5 に示す。重量減少には 誘導期がみられ，220てでの熱処理の場合を除いて，8時 間のアミン処理では重量減少は微々たるものであった。

図 5からわかるように，熱処理を施した䄉維の重量减 少速度が最大を示すアミン処理時間は，熱処理淐度が高 いはど短時間側にずれ，ピークの高さは城少する傾向に ある。220Cで熱処理した場合には，特にピークの広が りが大きく，非対称に長時間側にすをを引いている。図 5 ○上うな，分解速度の熱処理温度に上る变化の頋向は， PET䋘維の場合にも同様に認められた。

表1に示したように，䄉維の結晶化度は熱好理温度が 高いはど大きくなっている。しかるに汉5から明らかな 上うに，末熱処理試料の場合は別之して，熱処理温度が 高いはどアミン姏理の初期の重量減少速度は大きくなっ

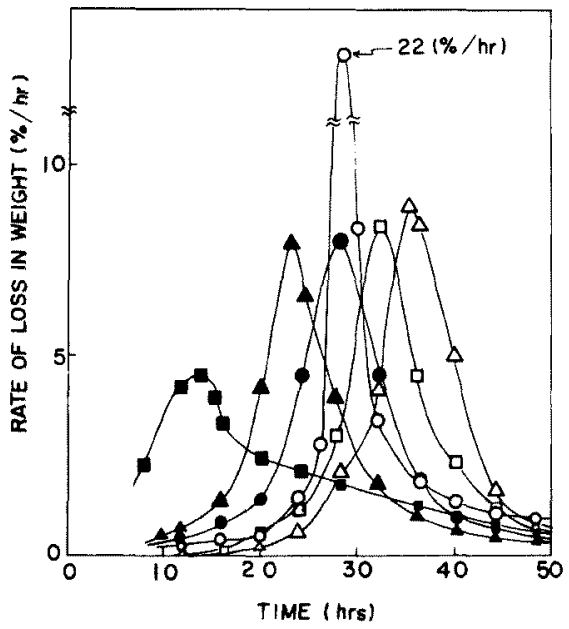

Fig. 5. Rate of loss in weight vs. time of aminolysis of PES fibers.

$O$; unheated

$\triangle$; heated at $120^{\circ} \mathrm{C}$

; heated at $180^{\circ} \mathrm{C}$ $\square$; heated at $150^{\circ} \mathrm{C}$
ている。これは，熱姏理により結晶化度の㙕大の効果を 上まわって，アミンの渗透に有利になるような微細構造 の変化が起こったととを示している。

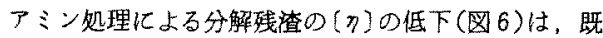
に指摘 ${ }^{2,8)}$ されているように，重量减少のはとんどみら れない短時間の狆理でも顕著で，重量減少で認められた 誘導期は，分解反応が起こらないためではなく，初期の 分子鎖の切断は重量减少に寄与しにくいためであること を示している。これはPET䄉維の $\mathrm{NaOH}$ 水溶液による 処理 ${ }^{10}$ では重量減少が加なり進行しても，残留物の $(\eta]$ はほよんど低下しないのと対照的である。

图6で，220熱婪理試料では，同じ重量减少率で他

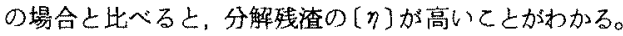
これは，220采の上うな高温の熱処理では，格子准な ビがより少なくなり，アミンの浸透し得ない結晶領域の 大きさが增大する，特に分子銧軸方向で增大するためと 推察される。

\section{3 熱処理温度を変えた緎維の染着性}

分散染料を用いて熱炕理䋐維の染着量を测定し，熱好 理温度上の関係調へた。PET織維の場合を図7に， またPES䋐維の場合を図8に示す。

PET緎維の熱姏理温度と染着鼠の関係は，狆理温度 が低い間は温度とともに染着量は低下して極小値をとり， その後反転して処理温度が $220^{\circ} \mathrm{Cを}$ 越えるような高温に なると増大するととが知られている゙ 13)。図7あるう いった傾向を示しているが，DEGを共縮合した図 80 場合には，染着量が増大し始める処理温度心かなり低く，

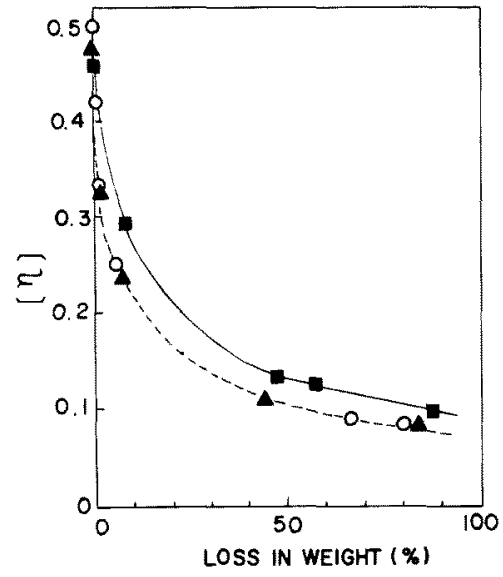

Fig. 6. Decrease in [ $\eta]$ of PES fibers by aminolysis ([ $\eta]$ vs. loss in weight).
$O$; unheated

$\Delta$; heated at $200^{\circ} \mathrm{C}$ 


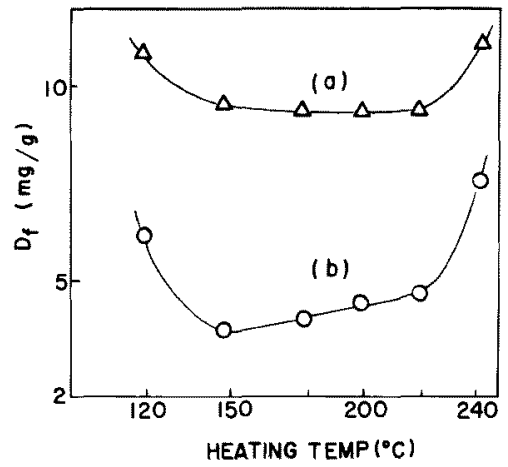

Fig. 7. Dye on fiber $\left(D_{f}\right)$ vs. heating temperature curves for the PET fiber, dyed at $98.5^{\circ} \mathrm{C}$. (a) Dispersol fast orange $B$

$$
(\text { (O) }-\mathrm{N}=\mathrm{N}-(\mathrm{O}-\mathrm{N}=\mathrm{N}-\mathrm{O}-\mathrm{O}-\mathrm{OH}) \text {. }
$$

(b) Eastman polyester red B.

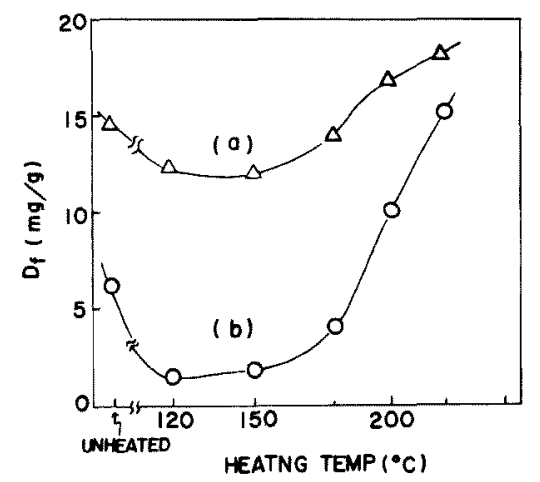

Fig. 8. Dye on fiber $\left(D_{f}\right)$ vs. heating temperature curves for the PES fiber dyed at $98.5^{\circ} \mathrm{C}$. (a) Dispersol fast orange $B$<smiles>CCCCCOc1cccc(N=NN=Nc2ccccc2)c1</smiles>

(b) Eastman polyester red $\mathrm{B}$.

$180^{\circ}$ Cの处理で明らか炕增大に転じていることがかかる。 先に示したように, PETおよびPESともに熱処理温 度が高いほど結晶化度は增大しているので，既偟指摘さ

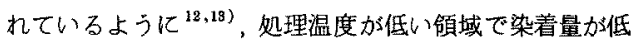
下するのは染着座席の減少として理解できるであるう。 一方，処理温度汃更汇高くなると染着量が反転して增大 するととについては，X線測定のData $\left(L P-D_{(\overline{\mathrm{i} 06)})}\right)$ 加ら 個々の非晶領域の長さ加增大し，粘弹性の測定結果加ら 処理温度が高くなる之非晶領城の分子銷の運動性が增大 するととがわかり，単位の非晶領域あたりの染着量が增
大して，全体では非晶分率の減少の勃果を上まわるため と考えられている2

本実験てかなり低温の熱処理で染着量の增大がみられ たPES繊維の場合について，いわゆる非晶の長さの尺 度とされる $L P-D_{\text {(106) }}$ を算出したところ，180Cあるい

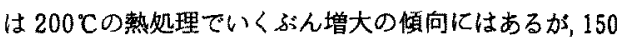
○あるいは 120 Cでの処理の場合と大差は認められなか った。しかるに図8で染着量をみれば，200Cの熱处理 で顕著に増大しており，てれは単仪非晶の長さだりでは 説明できないととを示している。

高温の熱処理による染着量の增大は，非晶の長さだけ でなく，3.1で示したように非晶領域にDEG成分に蒚む

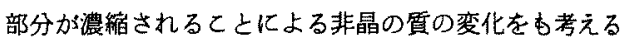
ととによって，よりよく説明できるであろう。非晶部分 亿DEG成分に富む部分が濃綰されると，非晶部分の分 子鎖の熱運動性加增大することは当然予想されるとしろ である。

五十風(1)は PET书よびメトキシポリエチレングリコ 一ル(MPEG)共縮合ポリエステル緉維に対する分散染 料の染着挙動を詳しく研究し，MPEG共縮合量の增大 は染色熱, 親和力および搪散保数の增大とエントロピー 変化招上び搪散のための活性化エネルギーの减少をもた らすことを認めた。またPET䋐維について高温の熱 処理は，MPEG共縮合量の增大の場合上同様な效果を もたらすととを認めている。てのような熱姏理による染 着挙動の変化は，非晶領域にDEG成分が濃縮されるよ うな非晶の質の変化を合せ考えることによって，上り明 確な説明ができるものと考えられる。

\section{4. 結言}

不均一系アミン分解反応を利用して，ポリエステル紋 維中のDEG成分か，アミンの浸透し易い非晶領域によ り多く分布し，その程度は高温で熱处理するはど影著に なるととを示した。このような微紐組織におけるDEG 成分の分布が，維維の染着性に与える影響についても論 じた。とのようなDEG成分の分布が生じるような微細 構造の変化は，染着性以外の䄉維物性にむなんらかの影 響を与えるものと推察され，今後の検討がまたれる。 付記：本研究の一部は第 17 回高分子討論会(松山, 1968 )で発表した。染着量の測定で㙝力を頂いた五十嵐 良一氏に感謝する。

\section{文献}

1) J. R. Winfield; Text. Res. J., 23, 289 (1953)

2) G. Farrow, D. A. S. Ravens, I. M. Ward; Polymer, 3, 17 (1962) 
3) 栗田利雄；高分子化学, 26, 551 (1969)

4) 関根 哲, 山本雄三，斉藤安史，木下茂武; 緉学誌。 31, $\mathrm{T}-203(1975)$

5) 斉藤安史, 関根 哲, 山本雄三，木下茂武; 瀻学誌， 32, $T-135(1976)$

6) 上総雄二郎, 岡 昌也; 未発表

7) W. H. Cobbs, Jr., R. L. Burton; J. Polymer Sci., 10, 275 (1953)

8) G. Farrow, D. Preston; Brit. J. Appl. Phys., $11,353(1960)$
9）暒谷浩一，上田 実；第 21 回高分子学会年次大会, 23 E 24 (1972)

10) 橋本 硉; 糡学誌, 14, 510 (1958)

11) D. N. Marvin; J. Soc. Dyers Colour., 70, 16 (1954)

12) E. Merian, J. Carbonell, U. Lerch, V. Sanahuja; J. Soc. Dyers Colour., 79, 505 (1963)

13）三石幸夫, 土浪 平; 䄉学誌，20，140(1964)

14) 五十嵐良一; 峨学誌，27，267(1971) 